Kalpa Publications in Civil Engineering
Volume 1, 2017, Pages 484-489
$\begin{gathered}\text { ICRISET2017. International Conference on Re- } \\ \text { search and Innovations in Science, Engineering } \\ \text { \&Technology. Selected papers in Civil Engineering }\end{gathered}$

\title{
Comparative Study of Triangle Tubes Bundled System and Square Tubes Bundled System
}

\author{
Jay P. Patel ${ }^{1}$, Vishal B. Patel ${ }^{2}$ and Elizabeth George ${ }^{3}$ \\ ${ }^{1}$ Research Scholar, Structural Engineering Department, Birla Vishvakarma Mahavidyalaya, \\ Vallabh Vidyanagar \\ ${ }^{2}$ Assistant Professor, Structural Engineering Department, Birla Vishvakarma Mahavidyalaya, \\ Vallabh Vidyanagar \\ ${ }^{3}$ Associate Professor, Structural Engineering Department, Birla Vishvakarma Mahavidyalaya, \\ Vallabh Vidyanagar
}

\begin{abstract}
Demand of construction of high-rise building is growing day by day in densely populated areas in India. In construction of tall building lateral load is main governing factor in design of tall structure. Tubular system is one of the common and popular systems. Framed tube and Bundled tube systems are commonly used systems in construction of high rise building. For designing these systems it requires accurate analysis. Here attempt has been made for 48 storey building structure using ETABS software in triangle tubes bundled system and square tubes bundled system.
\end{abstract}

\section{Introduction}

Bundled tube is one of the efficient system for resisting lateral load. Generally tall buildings require more focus on resisting lateral load. There are many lateral load resisting systems available but tubular system is one of the efficient and common system to resist lateral load. Father of tubular system is Fazlur R. khan. Most commonly used tubular systems are framed tube, Bundled tube, Tube in tube system and braced tube system. In tubular system periphery columns are closely spaced and jointed by deep spandrel beam. Gravity load is shared between external and internal column. Bundled tube system is system consists of number of tubes tied together which acts as one system. Columns in Bundled system are more evenly stressed and provide greater lateral stiffness to structure. Bundled tube system's construction can be done by both steel and concrete material. Generally in bundled tube system tubes can be in different shapes like square, triangle, trapezoidal, rectangle etc. 


\section{Literature Survey}

Ali and Moon [1] presented the different lateral load resisting system and history of development of tall structure system. The classification of tall building structural system was shown through reviewing elite work done. Sears tower is the 1st steel bundled tube structure. One Magnificent Mile of 1983 in Chicago is example of concrete bundled tube. Carnegie Hall Tower (New York, USA, 62 stories, $230.7 \mathrm{~m}$ ) is also concrete bundled tube structure. The individual tubes can be in different shapes such as square, triangular, rectangular or trapezoidal in the bundled tube system and also discussed the recent development in form of tall building. Nouri and Ashtari [2] investigated the solution for reducing shear lag and proposed the computer program which is capable of evaluating edge columns and spandrel beam stiffness factors in order to achieve the optimum design. Wind load is the governing design factor in most of the real world designs of tall buildings this program also enabled to assign the wind load to the frames. Sarath and Claudiajeyapushpa [3] carried out the work on shear wall system and framed tube system for 30, 40, 50 and 60 storey structures and seen that the shear wall system is significantly effective in resisting lateral loads for the structures up to 30 stories and beyond 30 stories the framed tube system is more effective. For the structure with framed tube, the maximum support reactions for outer periphery supports are much less compared to that of the Shear wall structure as the columns are very close to each other. Patel and Patel [4] carried out analysis and design for tubular system after assigning dead load, live load, lateral earthquake load and wind load. For earthquake loads, both static and response spectrum analysis were done. The buildings are considered to be located in zone- $\mathrm{V}$ to consider extreme conditions of lateral loads and concluded that displacements on each story and story drifts are observed to be less in diagrid compared to conventional frame and can provide large spacing between exterior columns for bundled tube system in compare to framed tube system. Bundled tube structural system has emerged as a better solution for lateral load resisting system in terms of lateral displacements, story drift, base shear and stiffness and it's stiff enough to resist wind force up to higher heights. Figure 1 shows the model of building with object of harmonic excitation and viscous damper.

\section{Objectives}

The main objective of this study is to comparing different parameters like Maximum storey displacement, Base shear, Maximum storey drift, Time period and Steel weight between triangle tubes bundled system and square tubes bundled system and conclude that which shape tubes bundled system is economic.

\section{Numerical Study}

In this paper 48 storey triangle tubes bundled system and square tubes bundled system are compared. Some general data required as follow 


\section{A. General data}

- Base plan area - 40m*40m

- Typical storey height $-3.6 \mathrm{~m}$

- Dead load - $1 \mathrm{kN} / \mathrm{m} 2$

- Live load - $2.5 \mathrm{kN} / \mathrm{m} 2$

- Steel grade - Fe250

- Concrete grade - M30

- Slab thickness - $180 \mathrm{~mm}$

- Wall thickness - $115 \mathrm{~mm}$

- Earthquake zone - V

- Importance Factor - 1.5

- Response reduction - 5

- Modal damping - $2 \%$

- Analysis - Static and response spectrum

- Basic wind speed - 50m/s

- Factor K1 - 1

- Factor K3 - 1

- Gust factor approach

\section{B. Modelling of the building}

For this study maximum storey displacement, Maximum storey drift, Time period, Base shear and steel weight results are obtained by using ETABS software.

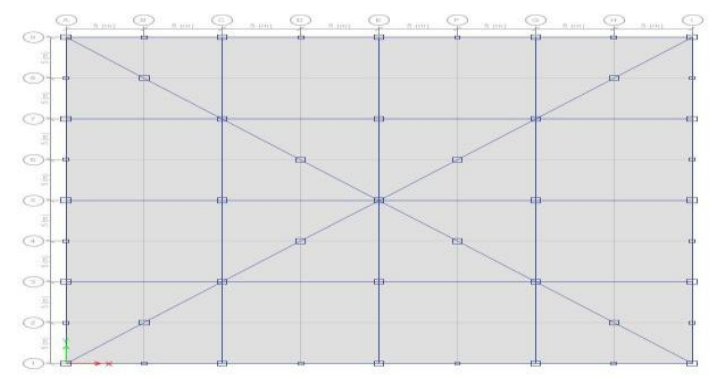

Figure 1: Plan of triangle tubes bundled system

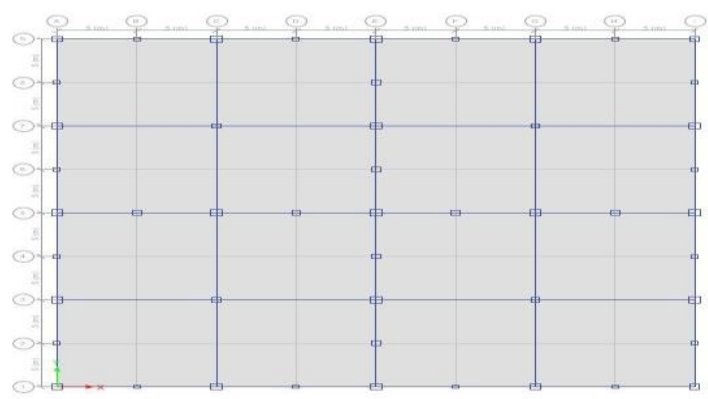

Figure 2 : Plan of the square tubes bundled system 


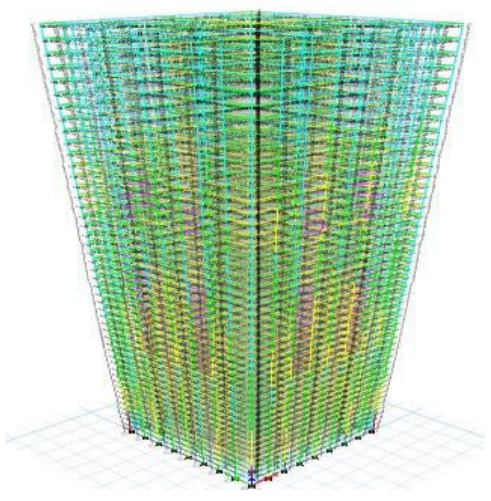

Figure 3 : 3-d view of triangle tubes bundled system

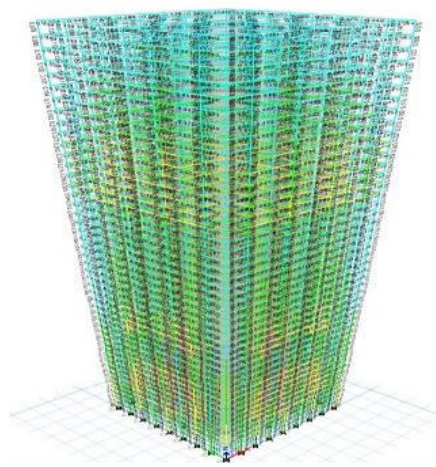

Figure 4 : 3-d view of Square tubes bundled system

\section{Result and Discussion}

Result comparison between triangle tubes bundled system and square tubes bundled system are shown as follow

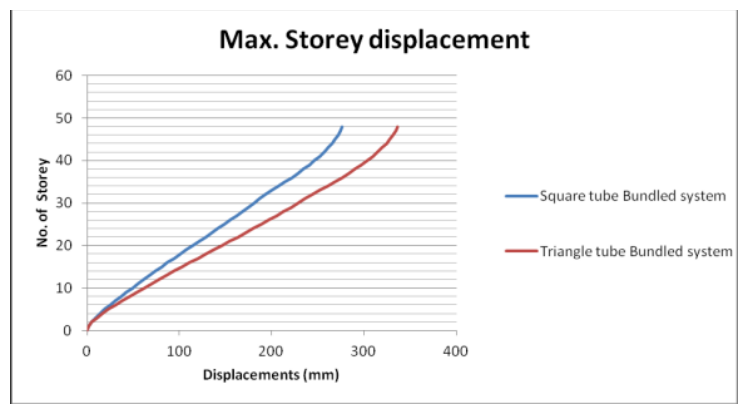

Figure 5 : Maximum storey displacement graph

Fig. 5 shows that the maximum storey displacement is $21.81 \%$ higher in triangle tubes bundled system than square tubes bundled system. 


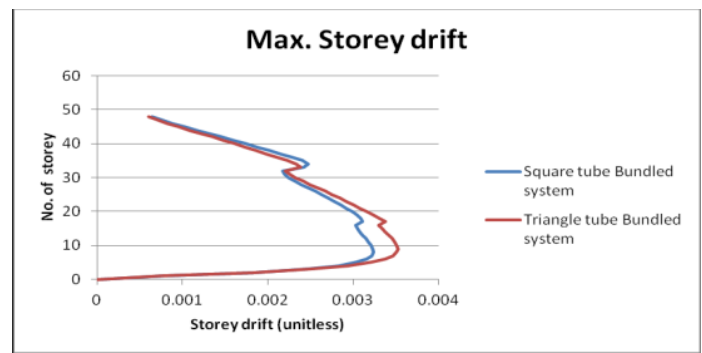

Figure 6: Maximum storey drift graph

Fig.6 shows that maximum storey drift value is $12.59 \%$ higher in triangle tubes bundled system as compared to square tubes bundled system.

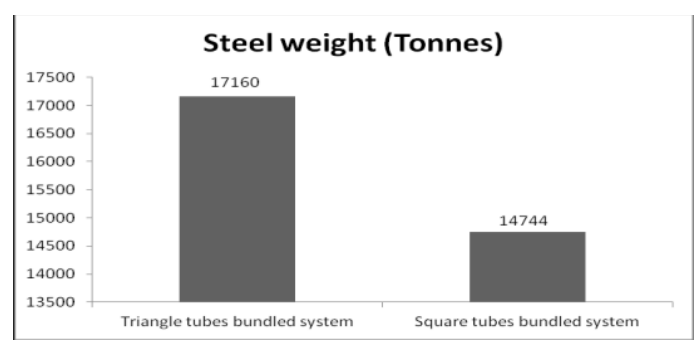

Figure 7 : Steel Weight graph

Fig.7 shows that the steel weight of the triangle tubes bundled system is $16.39 \%$ higher than the square tubes bundled system means square tube bundled system is economical

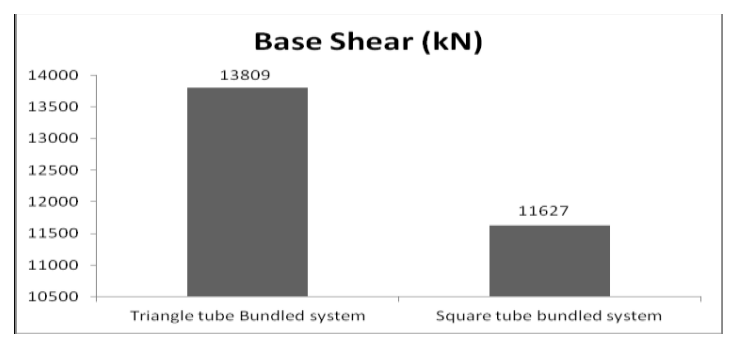

Figure 8 : Base shear graph

Fig.8. shows the base shear value of triangle tubes bundled system is $18.76 \%$ higher as compared to square tubes bundled system.

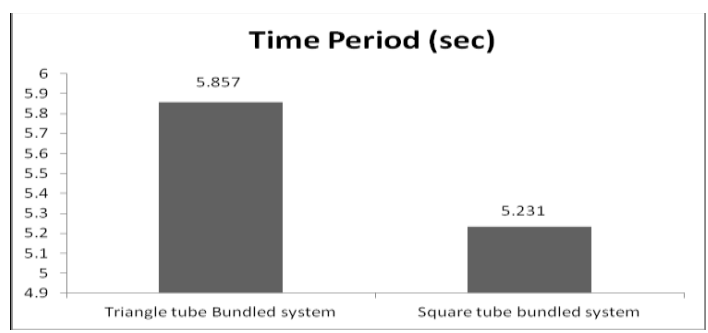

Figure 9: Time period graph

Fig.9 shows that the time period of triangle tubes bundled system is $11.97 \%$ higher than square tubes bundled system. 


\begin{tabular}{|c|c|c|}
\hline & $\begin{array}{c}\text { Square Tubes } \\
\text { Bundled System }\end{array}$ & $\begin{array}{c}\text { Triangle Tubes } \\
\text { Bundled System }\end{array}$ \\
\hline $\begin{array}{c}\text { Max. Storey } \\
\text { Displacement(mm) }\end{array}$ & 276.58 & 336.91 \\
\hline Max. Storey Drift & 0.003233 & 0.00364 \\
\hline Base Shear (kN) & 11627.17 & 13809 \\
\hline Time Periods (sec.) & 5.23 & 5.86 \\
\hline $\begin{array}{c}\text { Steel Weights } \\
\text { (Tonnes) }\end{array}$ & 14744 & 17160 \\
\hline
\end{tabular}

Table 1: Analysis Result of Square Tubes Bundled System and Triangle Tubes Bundled System

\section{Conclusion}

From the results of the present study, the following conclusions are drawn

(1) It is observed that upto 48 storey main governing lateral load is Static Earthquake load.

(2) Square tubes bundled system is more economical than triangle tubes bundled system.

\section{References}

Mir M., Ali; Moon, Kyoung Sun; " Structural Developments in Tall Buildings: Current Trends and Future Prospects " Architectural Science Review, University of Sydney, Volume 50, Number 3, PP: 205-233, 2007

Farshid nouri and Payam ashtari(2013), "Investigation of the shear lag phenomenon and structural behaviour of framed-tube and braced-tube tall structures", International Conference on Civil Engineering Architecture \& Urban Sustainable Development 27\&28 November 2013, Tabriz , Iran Vol:-14.

Sarath and D. Claudiajeyapushpa(2015) "Comparative Seismic Analysis Of An Irregular Building With A Shear Wall And Frame Tube System Of Various Sizes", International Journal Of Engineering And Computer Science ISSN:2319-7242, Vol:-4

Shaival J. Patel, Prof. Vishal B. Patel (2016), "Comparison of Different Types of Tubular Systems", International Journal Of Advanced Research Engineering science and technology,ISSN:2393-9877, Vol:-3, Issue-2. 